\title{
Aktivitas Antibakteri Minyak Atsiri Daun Tembakau terhadap Pertumbuhan Bakteri Escherichia coli dan Staphylococcus aureus
}

\author{
Antibacterial Activities of Tobacco Leaf Essential Oil Against Escherichia coli and \\ Stapphylococcus aureus
}

\author{
Elda Nurnasari*, Kristiana Sri Wijayanti \\ Balai Penelitian Tanaman Pemanis dan Serat, Karangploso, Malang, Indonesia \\ *Email: eldanurnasari@yahoo.com
}

Diterima:18 Desember 2018

Direvisi: 27 Januari 2019

Disetujui: 22 Februari 2019

\begin{abstract}
Abstrak
Tanaman tembakau banyak dimanfaatkan sebagai bahan baku rokok, namun hasil penelitian menunjukkan bahwa daun tembakau mengandung senyawa aktif yang dapat digunakan dalam bidang farmasi dan kesehatan. Daun tembakau mengandung minyak atsiri yang memiliki aroma khas. Penelitian ini bertujuan untuk menguji aktivitas antibakteri minyak atsiri tembakau yang berasal enam sentra yaitu Temanggung, Yogyakarta, Purwodadi, Boyolali, Blitar, dan Probolinggo. Minyak atsiri tembakau diperoleh dengan metode distilasi uapair. Pengujian aktivitas antibakteri dilakukan dengan metode difusi dan uji konsentrasi hambat tumbuh minimum dilakukan terhadap dua bakteri yakni Escherichia coli dan Staphylococcus aureus. Rendemen minyak atsiri daun tembakau berkisar antara 0,54-3,39\%. Minyak atsiri daun tembakau memiliki aktivitas antibakteri terhadap bakteri $E$. coli dan $S$. aureus dari daun tembakau Yogyakarta sebesar $26 \mathrm{~mm}$, sedangkan untuk bakteri E. coli zona hambat terbesar pada minyak atsiri daun tembakau Blitar yakni sebesar $21 \mathrm{~mm}$. Besarnya zona hambat ini tidak berbeda jauh dengan zona hambat pada pengujian antibiotik tetrasiklin sebagai kontrol positif yakni $25 \mathrm{~mm}$ pada bakteri S. aureus dan $21.5 \mathrm{~mm}$ pada bakteri E. coli. Minyak atsiri daun tembakau asal Probolinggo mampu menghambat pertumbuhan bakteri S. aureus mulai konsentrasi $6,25 \%$ dan bakteri E. coli mulai konsentrasi $12,5 \%$.
\end{abstract}

Kata kunci: Minyak atsiri; Daun tembakau; Antibakteri; Escherichia coli; Staphylococcus aureus

\begin{abstract}
Tobacco plants are widely used as raw material for cigarettes, but the results of the study show that in tobacco leaves contain compounds that can be used in the pharmaceutical and health fields. Tobacco leaves contain essential oils that have a distinctive aroma. The study aims to examine the antibacterial activity of tobacco essential oil from six sources tobacco such as Temanggung, Yogyakarta, Purwodadi, Boyolali, Blitar and Probolinggo. Tobacco essential oil is obtained by the steam-water distillation method. Antibacterial activity evaluation was carried out by diffusion method and the minimum inhibitory concentration on two bacteria, Escherichia coli and Staphylococcus aureus. The yield of tobacco essential oil ranged from 0.54-3.39\%. Tobacco essential oil had antibacterial activity against bacteria E. coli and S. aureus in the presence of inhibition zones in bacterial media. The biggest inhibition zone was in Yogyakarta tobacco essential oil of 26 mm for S. aureus bacteria, while for bacteria the biggest inhibition zone was Blitar tobacco essential oil which was equal to $21 \mathrm{~mm}$. The inhibition zone was not much different E. coli from the inhibition zone in tetracycline antibiotic testing (positive control) which was $25 \mathrm{~mm}$ in $\mathrm{S}$. aureus and $21.5 \mathrm{~mm}$ bacteria in E. coli bacteria. Tobacco essential oil from Probolinggo was able to inhibit the growth of $S$. aureus bacteria up to a concentration of $6.25 \%$ and E. coli bacteria to a concentration of $12.5 \%$.
\end{abstract}

Keywords: Essential oils; Tobacco leaf; Antibacterial; Escherichia coli; Staphylococcus aureus 


\section{PENDAHULUAN}

Tanaman menghasilkan senyawa metabolit primer dan sekunder. Metabolit primer bersifat esensial dalam proses metabolisme sel dan proses sintesis pada tanaman tersebut. ${ }^{1}$ Metabolit sekunder adalah senyawa yang dihasilkan oleh tanaman sebagai mekanisme pertahanan terhadap predator dan mikroorganisme patogen.

Minyak atsiri merupakan salah satu senyawa metabolit sekunder yang dihasilkan oleh tanaman yang memiliki bau atau aroma khas. Minyak atsiri adalah campuran senyawa volatil yang beraroma kuat dan memiliki susunan senyawa kompleks. Minyak atsiri memiliki aktivitas farmakologi antara lain antiseptik, bakterisida, virusida, fungisida, dan sifatsifat farmakologi yang lain. ${ }^{2}$

Minyak atsiri umumnya dijumpai pada jenis tanaman yang memiliki bau atau aroma. Tembakau merupakan salah satu tanaman yang memiliki aroma yang khas. Daun tembakau mengandung minyak atsiri dengan rendemen berkisar antara 0,0267 $0,8428 \%$. ${ }^{3}$ Hasil penelitian meyebutkan bahwa minyak atsiri tembakau memiliki aktivitas antibakteri terhadap Escherichia coli, Staphylococcus aureus, dan Pseudomonas aeruginosa. ${ }^{4}$

Bakteri patogen seperti E. Coli dan $S$. aureus merupakan bakteri penyebab infeksi pada manusia. Masyarakat mengobati penyakit infeksi akibat bakteri menggunakan antibiotik yang mudah diperoleh seperti tetrasiklin, ampisilin, atau antibiotika jenis lainnya. Pemakaian antibiotik secara berlebihan dan dengan dosis yang kurang tepat dapat mengakibatkan terjadinya resistensi antibotik. ${ }^{5}$ Adanya resistensi terhadap antibiotik memerlukan alternatif senyawa antibakteri lain yang dapat berasal dari bahan alami. Salah satu yang potensial adalah minyak atsiri daun tembakau.

Isolasi minyak atsiri daun tembakau juga merupakan langkah diversifikasi produk tembakau non rokok. Minyak atsiri tembakau dapat diperoleh dari hasil samping pertanian tembakau seperti daun tembakau yang memiliki mutu rendah dan bunga tembakau. Hasil penelitian sebelumnya daun tembakau yang tidak laku dijual dapat menghasilkan minyak atsiri dengan rendemen $3,25 \%$ menggunakan metode ekstraksi pelarut. Minyak atsiri tersebut mengandung 91 senyawa kimia dengan neofitadiena sebagai senyawa utama. ${ }^{6}$ Penelitian ini bertujuan untuk menguji aktivitas antibakteri minyak atsiri daun tembakau di enam sentra terhadap bakteri E.coli dan $S$. aureus.

\section{METODE}

Desain penelitian ini adalah eksperimental laboratorium. Kegiatan yang dilakukan adalah preparasi sampel, ekstraksi minyak atsiri daun tembakau, uji aktivitas antibakteri, dan uji konsentrasi hambat tumbuh minimum.

\section{Alat dan bahan}

Peralatan yang digunakan adalah seperangkat alat destilasi uap-air, rotary vacuum evaporator, autoklaf, shaking incubator, inkubator, Laminar Air Flow (LAF), dan spektrofotometer (Spektrophotometer $600 \mathrm{UV}-\mathrm{Vis}$ Thermo Scientific), Gas Chromatography-Mass Spectrometry (GC-MS) (Shimadzu QP2010S)

Bahan yang digunakan adalah daun tembakau rajangan yang diperoleh dari enam daerah penghasil tembakau, yaitu Yogyakarta (tembakau Yogyakarta), Temanggung (tembakau Temanggung), Boyolali (tembakau Boyolali), Purwodadi (tembakau Purwodadi), Blitar (tembakau Blitar), dan Probolinggo (tembakau Paiton), isolat E. coli dan S.aureus dari Food and Nutrition Culture Collection (FNCC) Pusat Studi Pangan dan Gizi Universitas Gajah Mada, Nutrient Agar (NA), Nutrient Broth (NB), tetrasiklin sebagai kontrol positif. 


\section{Preparasi sampel}

Sampel daun tembakau yang digunakan dalam penelitian ini berasal dari enam daerah sentra tembakau yaitu Temanggung, Yogyakarta, Purwodadi, Boyolali, Blitar dan Probolinggo. Daun tembakau rajangan kering sebelum dilakukan destilasi uap-air dipotong kecilkecil, disaring, dan diayak dengan saringan 10 mesh.

\section{Ekstraksi minyak atsiri daun tembakau}

Sebanyak 796,2 gram daun tembakau Temanggung,706,9 gram daun tembakau Yogyakarta, 535,7 gram daun tembakau Purwodadi, 683,4 gram daun tembakau Boyolali, 437,9 gram daun tembakau Blitar dan 446,2 gram daun tembakau Probolinggo didistilasi menggunakan metode distilasi uap selama \pm 6 jam. Hasil distilasi ditampung kemudian dipekatkan sehingga air dan minyak terpisah. Minyak atsiri yang diperoleh selanjutnya disimpan untuk uji aktivitas antibakteri.

\section{Uji aktivitas antibakteri dengan metode difusi $^{7}$}

Sebanyak satu ose bakteri dari stok biakan diambil lalu diinkubasi dalam 10 $\mathrm{mL}$ medium cair NB selama 20 jam pada suhu $37{ }^{\circ} \mathrm{C}$ dan dihomogenkan. Medium NA sebanyak $15 \mathrm{~mL}$ pada suhu $\pm 40^{\circ} \mathrm{C}$ dituangkan ke dalam cawan petri steril dan didiamkan pada suhu kamar sampai memadat.

Sejumlah biakan bakteri dalam medium cair NB diambil dan disebarkan di dalam medium NA lalu diukur absorbansinya pada panjang gelombang $600 \mathrm{~nm}$. Jika nilai absorbansinya $\leq 0,5$ maka diambil 100 $\mu \mathrm{L}$ biakan bakteri sedangkan jika absorbansinya 0,6-1,0 biakan bakteri yang diambil $50 \mu \mathrm{L}$.

Tetrasiklin sebagai kontrol positif ditimbang $100 \mathrm{mg}$ kemudian dilarutkan dengan akuades steril sampai $1 \mathrm{~mL}$ sehingga diperoleh larutan stok tetrasiklin $10 \%$. Larutan stok tetrasiklin $10 \%$ kemudian diencerkan dengan mengambil 7,5 $\mu \mathrm{L}$ dilarutkan dalam akuades steril sampai $500 \mu \mathrm{L}$ sehingga diperoleh konsentrasi tertrasiklin $0,15 \%$. Media NB tanpa penambahan larutan uji dan kontrol positif digunakan sebagai kontrol negatif.

Media yang telah diinokulasi kultur bakteri uji dilubangi dengan diameter \pm 8 $\mathrm{mm}$. Sampel minyak atsiri dan larutan kontrol dimasukkan ke dalam lubang tersebut lalu diinkubasi pada suhu $37^{\circ} \mathrm{C}$ selama $20 \mathrm{jam}$. Zona hambat yang terlihat bening di sekeliling lubang menandakan adanya aktivitas antibakteri. Zona hambat yang terbentuk diukur menggunakan penggaris.

\section{Pengujian konsentrasi hambat tumbuh minimum (KHTM) ${ }^{8}$}

Setelah aktivitas antibakteri minyak atsiri daun tembakau diketahui tahap selanjutnya menentukan KHTM minyak atsiri terhadap bakteri uji. Variasi konsentrasi yang digunakan untuk menentukan KHTM pada penelitian ini yaitu $100 \%, 50 \%, 25 \%, 12,5 \%, 6,25 \%$, $3,125 \%, 1 \%$, dan $0,5 \%$ (v/v).

Pengamatan dilakukan dengan mengamati kejernihan media. Media yang jernih, kemudian ditanam dengan metode streak plate. Prosedur yang dilakukan adalah media NA yang telah dimasak dimasukkan ke dalam cawan petri $\pm 22 \mathrm{ml}$ dan dibiarkan sampai padat. Inokulan diambil pada tabung dengan media yang jernih, digoreskan pada cawan petri, dan diinkubasi pada suhu $37{ }^{\circ} \mathrm{C}$ selama $18-24$ jam. Pertumbuhan bakteri diamati untuk hasil Konsentrasi Bunuh Minimum (KBM).

\section{HASIL DAN PEMBAHASAN}

Hasil distilasi uap-air sampel daun tembakau yang berasal dari enam lokasi yakni Temanggung, Boyolali, Yogyakarta, Purwodadi, Blitar, dan Probolinggo diperoleh rendemen minyak atsiri berkisar antara 0,54-3,39\%. Berat daun tembakau yang digunakan tidak sama karena menyesuaikan ketersediaan sampel daun tembakau yang ada. Pemilihan lokasi 
pengambilan sampel berdasarkan ketersediaan sampel diluar musim panen.

Ekstraksi minyak atsiri daun tembakau menggunakan metode distilasi uap-air karena metode ini merupakan metode yang sederhana dan murah. Kelebihan dari metode ini adalah penetrasi uap lebih merata dan dapat masuk ke dalam jaringan tanaman, dan suhu yang dapat dipertahankan sampai $100{ }^{\circ} \mathrm{C}$. Keuntungan yang lain adalah waktu penyulingan lebih singkat dan rendemen minyak atsiri lebih besar bila dibandingkan dengan metode distilasi air. $^{9}$

Minyak atsiri tembakau memiliki aroma yang khas dan kuat karena mengandung senyawa aromatis. Minyak atsiri dari tembakau oriental Prilep memiliki aktivitas antibakteri sebesar 15 $\mathrm{mm}$ pada bakteri $E$. coli dan $15,2 \mathrm{~mm}$ pada bakteri $S$. aureus. ${ }^{4}$ Antibakteri merupakan senyawa kimia khusus yang dihasilkan oleh organisme hidup dalam konsentrasi rendah serta dapat menghambat proses penting mikroorganisme. ${ }^{10,1}$

Hasil uji aktivitas antibakteri minyak atsiri daun tembakau menunjukkan dapat menghambat pertumbuhan bakteri $E$. coli dan $S$. aureus yang ditandai dengan adanya zona bening di sekitar lubang sampel. Diamater zona hambat terlihat dari zona bening di sekitar lubang. Jika semakin luas zona bening maka semakin besar suatu bahan dalam menghambat pertumbuhan bakteri. Data besarnya zona hambat disajikan pada Tabel 1.

Zona hambat terbesar untuk bakteri S.aureus diperoleh dari minyak atsiri tembakau Yogyakarta sebesar $26 \mathrm{~mm}$, sedangkan untuk bakteri $E$. coli zona hambat terbesar diperoleh dari minyak atsiri tembakau Blitar yakni sebesar 21 $\mathrm{mm}$. Pengukuran zona hambat bakteri pada penelitian ini menggunakan metode difusi. Metode difusi dengan menggunakan sumuran lebih sensitif dibandingkan dengan cakram. Susanto, dkk. mengategorikan diameter zona hambat sesuai dengan kekuatan daya hambatnya. Kategori lemah, sedang, kuat, dan sangat kuat secara berturut-turut adalah diameter zona hambat $\leq 5,6-10,11-20$, dan $\geq 21$ $\mathrm{mm} .{ }^{12}$ Berdasarkan kategori zona hambat tersebut maka minyak atsiri tembakau Blitar memiliki zona hambat yang kuat terhadap bakteri E.coli dan S.aureus dengan zona hambat sebesar $21 \mathrm{~mm}$ dan $24,5 \mathrm{~mm}$ (Tabel 1). Hasil pengujian aktivitas antibakteri minyak atsiri daun tembakau dapat dilihat pada Gambar 1, 2, dan 3 .

Tetrasiklin sebagai kontrol positif untuk uji aktivitas antibakteri merupakan golongan antibiotik spektrum luas. Tetrasiklin memiliki kemampuan melawan sejumlah besar patogen diantaranya adalah bakteri gram positif ( $S$. aureus) dan bakteri gram negatif (E. coli). ${ }^{13}$

Tabel 1. Hasil uji aktivitas antibakteri enam minyak atsiri tembakau terhadap bakteri E. coli dan S. aureus

\begin{tabular}{lcc}
\hline \multirow{2}{*}{ Jenis minyak atsiri tembakau } & \multicolumn{2}{c}{ Rata-rata zona hambat $(\mathrm{mm})$} \\
\cline { 2 - 3 } & E. coli & S. aureus \\
\hline Tembakau Temanggung & 13,25 & 25,75 \\
Tembakau Boyolali & 6,00 & 22,25 \\
Tembakau Yogyakarta & 10,75 & 26,00 \\
Tembakau Purwodadi & 0,00 & 14,50 \\
Tembakau Blitar & 21,00 & 24,50 \\
Tembakau Probolinggo & 1,30 & 8,50 \\
Kontrol negatif & 0,00 & 0,00 \\
Kontrol positif & 21,50 & 25,00 \\
\hline
\end{tabular}




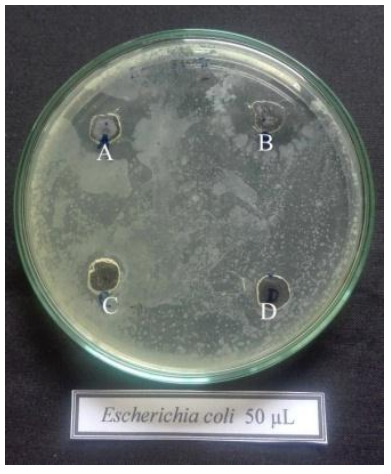

(1)

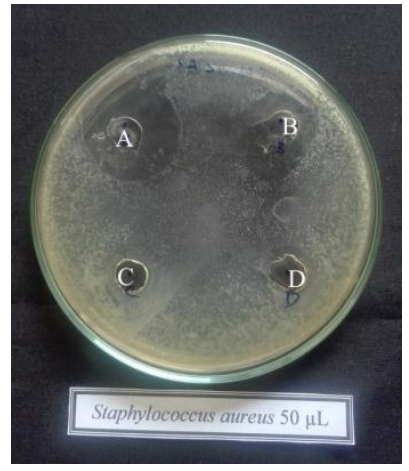

(2)

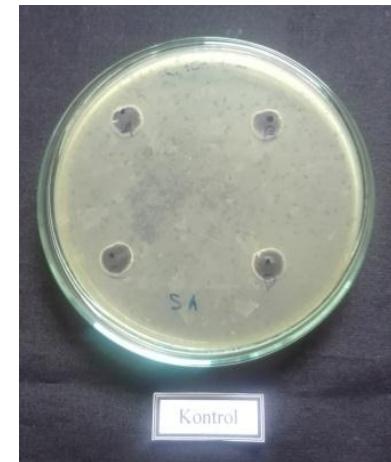

(3)

Gambar 1. Hasil uji aktivitas antibakteri (zona hambat) (1) Bakteri E. coli (2) Bakteri S. aureus (3) Kontrol negatif (A: tembakau Temanggung B: tembakau Yogyakarta C: tembakau Boyolali D: tembakau Purwodadi)

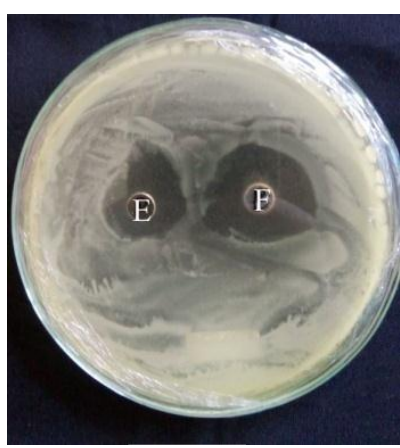

(1)

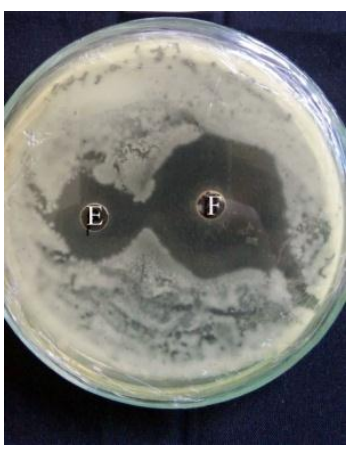

(2)

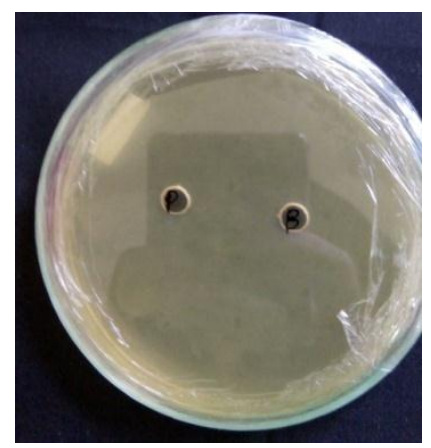

(3)

Gambar 2. Hasil uji aktivitas antibakteri (zona hambat) (1) Bakteri E. coli (2) Bakteri S. aureus (3) Kontrol negatif (E: tembakau Probolinggo F: tembakau Blitar)

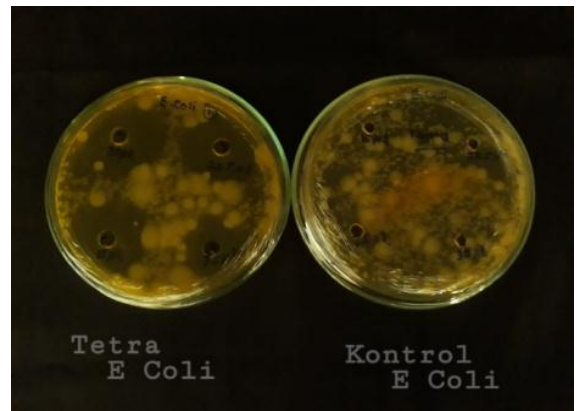

(a)

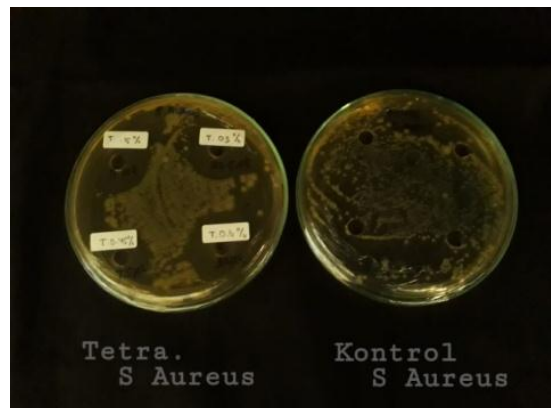

(b)

Gambar 3. Zona hambat antibiotik tetrasiklin terhadap bakteri (a) E. Coli dan (b) S. aereus

Mekanisme kerja tetrasiklin dengan menghambat sintesis protein pada ribosom bakteri. Tetrasiklin masuk ke dalam bakteri melalui dua proses yaitu difusi pasif dan transport aktif. Setelah tetrasiklin masuk ke dalam ribosom maka akan berikatan dengan ribosom 30 s dan menghalangi masuknya kompleks tRNA-asam amino pada lokasi asam amino sehingga proses sintesis protein tidak dapat berlangsung 
yang mengakibatkan bakteri tidak dapat bermetabolisme. ${ }^{14,15}$

Hasil uji GCMS menunjukkan bahwa salah satu kandungan senyawa utama dalam minyak atsiri daun tembakau adalah piridin. Piridin termasuk dalam golongan alkaloid. Senyawa alkaloid memiliki kemampuan sebagai antibakteri dengan mekanisme aksi mengganggu komponen penyusun peptidoglikan pada sel bakteri sehingga lapisan dinding sel tidak terbentuk secara utuh dan menyebabkan kematian sel tersebut. Selain itu, alkaloid juga menghambat pembentukan sintesis protein sehingga dapat mengganggu metabolisme bakteri. ${ }^{16}$ Hasil yang hampir sama diperoleh pada pengujian aktivitas antibakteri ekstrak kulit manggis yang juga mengandung senyawa alkaloid, dimana ekstrak kulit manggis mampu menghambat pertumbuhan bakteri $E$. coli dan memiliki kesetaraan dengan antibiotik tetrasiklin. ${ }^{17}$ Senyawa alkaloid merupakan senyawa metabolit sekunder yang digunakan oleh tanaman sebagai mekanisme pertahanan diri dari serangan bakteri patogen dan predator. $^{18}$

\section{Konsentrasi hambat tumbuh minimum (KHTM)}

Uji Konsentrasi Hambat Tumbuh Minimum (KHTM) bertujuan untuk mengetahui konsentrasi minimal suatu bahan yang dapat digunakan untuk menghambat pertumbuhan bakteri. Hasil uji KHTM minyak atsiri dari 6 sampel daun tembakau terhadap bakteri $E$. coli dan $S$. aureus menunjukkan bahwa positif menghambat pada berbagai konsentrasi (Tabel 2). Hasil penelitian Puspita menyebutkan bahwa ekstrak daun tembakau pada konsentrasi $20 \%$ b/v dapat menghambat $S$. aureus dan $E$. coli namun kemampuannya cenderung lemah, dan tergolong sedang pada konsentrasi $40 \%$ $60 \%(\mathrm{~b} / \mathrm{v}){ }^{19}$

\section{Tabel 2. Pengaruh penggunaan minyak atsiri daun tembakau terhadap kadar hambat} tumbuh minimum bakteri $E$. coli dan $S$. aureus

\begin{tabular}{ccccccc}
\hline Konsentrasi & \multicolumn{7}{c}{ Hasil uji KHTM bakteri E. coli } \\
\cline { 2 - 7 } minyak atsiri & Tembakau & Tembakau & Tembakau & Tembakau & Tembakau & Tembakau \\
tembakau & Temanggung & Boyolali & Yogyakarta & Purwodadi & Blitar & Probolinggo \\
\hline Kontrol (+) & - & - & - & - & - & - \\
$100 \%$ & - & - & - & - & - & - \\
$50 \%$ & + & - & - & - & + & - \\
$25 \%$ & + & - & - & - & + & - \\
$12,5 \%$ & + & + & + & + & + & - \\
$6,25 \%$ & + & + & + & + & + & + \\
$3,125 \%$ & + & + & + & + & + & + \\
Kontrol (-) & + & + & + & + & + & + \\
\hline Konsentrasi & & \multicolumn{7}{c}{ Hasil uji KHTM bakteri S. aureus } & \\
minyak atsiri & Tembakau & Tembakau & Tembakau & Tembakau & Tembakau & Tembakau \\
tembakau & Temanggung & Boyolali & Yogyakarta & Purwodadi & Blitar & Probolinggo \\
\hline Kontrol (+) & - & - & - & - & - & - \\
$100 \%$ & - & - & - & - & - & - \\
$50 \%$ & + & - & - & - & + & - \\
$25 \%$ & + & - & + & - & + & - \\
$12,5 \%$ & + & + & + & + & + & - \\
$6,25 \%$ & + & + & + & + & + & - \\
$3,125 \%$ & + & + & + & + & + & + \\
Kontrol (-) & + & + & + & + & + & + \\
\hline
\end{tabular}

Keterangan: (-): jernih (menghambat)

(+): keruh (tidak menghambat) 
Pada Tabel 2 menunjukkan bahwa minyak atsiri daun tembakau asal Probolinggo mampu menghambat pertumbuhan E. coli dan $S$. aureus pada konsentrasi $12,5 \%$ dan 6,25\%.

Kemampuan minyak atsiri daun tembakau dalam menghambat pertumbuhan bakteri tergantung pada beberapa faktor antara lain konsentrasi minyak atsiri, kandungan senyawa aktif dalam minyak atsiri serta jenis bakteri.

Konsentrasi minyak atsiri sangat memengaruhi daya hambat pertumbuhan bakteri. Semakin tinggi konsentrasi minyak atsiri maka semakin kuat daya hambatnya. Hal ini terlihat pada Tabel 2 dimana pada konsentrasi $100 \%$ semua jenis minyak atsiri dapat menghambat pertumbuhan bakteri E. coli dan S. aureus.

Kandungan senyawa aktif dalam minyak atsiri secara kuantitatif dan kualitatif tergantung pada beberapa faktor antara lain jenis tembakau, tanah dan iklim, ukuran daun, waktu panen, cara pengeringan daun, umur tanaman dan waktu pengeringan. ${ }^{20}$ Minyak atsiri tembakau asal Probolinggo mampu menghambat pertumbuhan bakteri $E$. coli dan $S$. aureus berturut-turut mulai dari 12,5 dan 6,25\%.

Hasil uji GC-MS menunjukkan minyak atsiri daun tembakau asal Probolinggo terdapat senyawa aktif piridin dengan luas area sebesar 12635464 (Gambar 4). Piridin merupakan salah satu jenis alkaloid.
Kandungan utama senyawa kimia dalam tembakau adalah alkaloid seperti nikotin, nornikotin, anatabin. Nikotin adalah suatu alkaloid dengan nama kimia 3-(1-metil-2pirolidil) piridin. Senyawa piridin dapat diperoleh dari senyawa nikotin yang mengalami perubahan struktur. Senyawa alkaloid bersifat basa sehingga mudah mengalami dekomposisi karena panas dan sinar. Perubahan ini dapat disebabkan karena proses destilasi dan proses pemurnian dengan rotary evaporator. ${ }^{21}$

Penelitian ini menunjukkan minyak atsiri tembakau dapat menghambat pertumbuhan bakteri $S$. aureus sampai konsentrasi $6,25 \%$ sedangkan pada bakteri E. coli hanya mampu menghambat sampai konsentrasi $12,5 \%$. Bakteri gram positif seperti $S$. aureus memiliki dinding sel yang relatif lebih sederhana, terdiri dari komponen peptidoglikan dan asam teikoat. $^{22}$ E. coli merupakan salah satu bakteri gram negatif. Bakteri gram negatif memiliki dinding sel yang lebih tebal karena terdiri dari peptigoglikan dan lebih banyak mengandung lipid. Bakteri gram negatif juga memiliki sistem membran luar berupa bilayer yang terdiri dari fosfolipid (lapisan dalam) dan lipopolisakarida (lapisan luar) yang bersifat nonpolar. Hal ini yang menyebabkan senyawa antibakteri lebih sulit untuk masuk ke dalam sel sehingga aktivitas antibakterinya lebih lemah dibandingkan dengan bakteri gram positif. $^{23}$

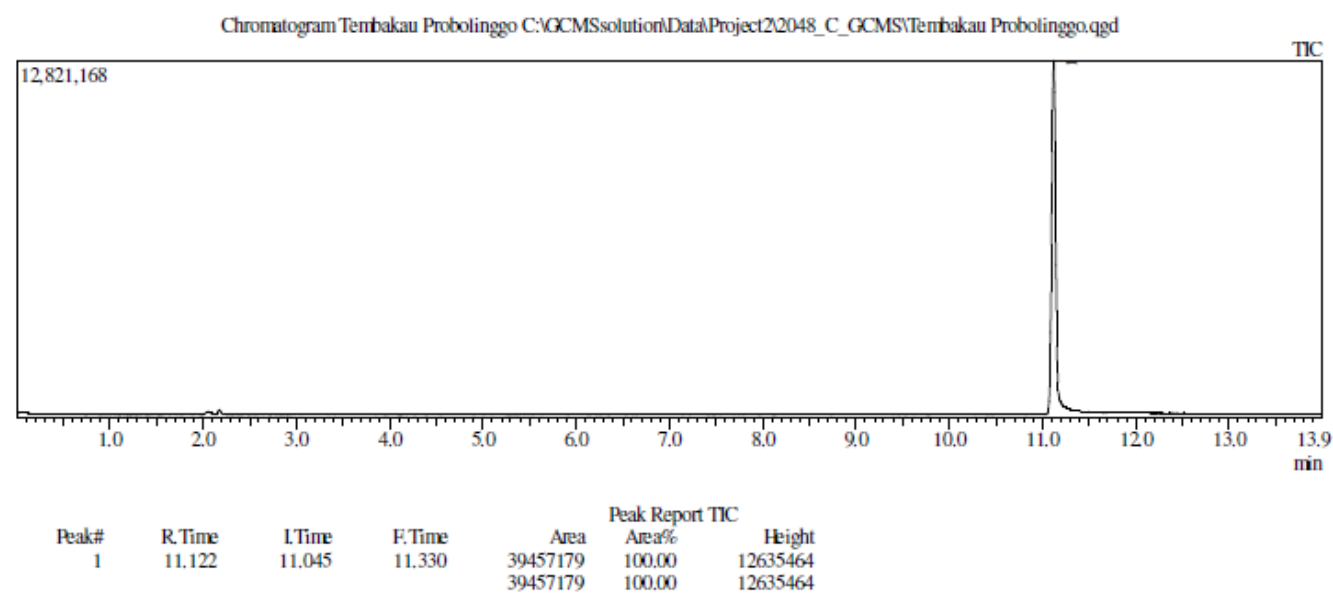

Gambar 4. Kromatogram GC-MS minyak atsiri tembakau Probolinggo 


\section{KESIMPULAN}

Minyak atsiri tembakau memiliki aktivitas antibakteri terhadap bakteri $E$. coli dan $S$. aureus dengan adanya zona hambat di media bakteri. Zona hambat terbesar pada minyak atsiri tembakau Yogyakarta sebesar $26 \mathrm{~mm}$ untuk bakteri $S$. aureus, sedangkan untuk bakteri $E$. coli zona hambat terbesar pada minyak atsiri tembakau Blitar yakni sebesar $21 \mathrm{~mm}$. Minyak atsiri tembakau asal Probolinggo mampu menghambat pertumbuhan bakteri S. aureus sampai konsentrasi $6,25 \%$ dan bakteri E. coli sampai pada konsentrasi $12,5 \%$.

\section{UCAPAN TERIMA KASIH}

Ucapan terima kasih ditujukan kepada Kepala Balai Penelitian Tanaman Pemanis dan Serat atas kesempatan untuk melaksanakan penelitian ini. Terima kasih juga disampaikan kepada saudara Heri Prabowo sebagai Penanggung jawab RPTP, serta kepada semua pihak yang telah membantu dalam pelaksanaan penelitian.

\section{DAFTAR PUSTAKA}

1. Nur Wahidah $\mathrm{R}$ dan PN. Analisis Senyawa Metabolit Primer Pada Jamur Merang. J Akad Kim. 2017;6(1):43-7.

2. de Alencar Filho JMT, Araújo LDC, Oliveira AP, Guimarães AL, Pacheco AGM, Silva FS, et al. Chemical composition and antibacterial activity of essential oil from leaves of croton heliotropiifolius in different seasons of the year. Brazilian J Pharmacogn [Internet]. 2017;27(4):440-4. Available from:

http://dx.doi.org/10.1016/j.bjp.2017.02. 004

3. Nurnasari E, Subiyakto. Komposisi kimia minyak atsiri pada beberapa tipe daun tembakau (Nicotiana tabaccum L.). Ber Biol [Internet]. 2011;10(5):571-80. Available from: file:///C:/Users/Saskara

Edi/Downloads/1913-3768-1-SM.pdf

4. Palic R, Stojanovic G, Alagic S, Nikolic M, Lepojevic Z. Chemical composition and antimicrobial activity of the essential oil and $\mathrm{CO} 2$ extracts of the oriental tobacco, Prilep. Flavour Fragr J. 2002;17(5):323-6.

5. Negara KS. Analisis Implementasi Kebijakan Penggunaan Antibiotika Rasional Untuk Mencegah Resistensi Antibiotika di RSUP Sanglah Denpasar: Studi Kasus Infeksi Methicillin Resistant Staphylococcus Aureus Analysis The Implementation Policy of Rational Use of Antibiot. J Adm Kebijak Kesehat. 2014;1(1):4250 .

6. Zhang X, Gao H, Zhang L, Liu D, Ye $\mathrm{X}$. Extraction of essential oil from discarded tobacco leaves by solvent extraction and steam distillation, and identification of its chemical composition. Ind Crop Prod [Internet]. 2012;39:162-9. Available from: http://dx.doi.org/10.1016/j.indcrop.201 2.02.029

7. Prayoga E. Perbandingan Efek Ekstrak Daun Sirih Hijau (Piper betle L.) dengan Metode Difusi Disk dan Sumuran terhadap Pertumbuhan Bakteri Staphylococcus aureus. Skripsi. Jakarta: Universitas Islam Negeri Syarif Hidayatullah.; 2013. 40 p.

8. Effendi F, Anna P, Ernie S. Uji Aktivitas Antibakteri Teh Kombucha Probiotik Terhadap Bakteri Escherichia coli dan Staphylococcus aureus. Fitofarmaka. 2014;4(2):34-41.

9. Armando, Rochim. Memproduksi Minyak Atsiri Berkualitas. I. Jakarta: Penebar Swadaya; 2009. 20 p.

10. Utami ER. Antibiotika, Resistensi, dan Rasionalitas Terapi. Saintis. 2012;1(1):124-38.

11. Rahmawati N, Sudjarwo E, Widodo E. Uji aktivitas antibakteri ekstrak herbal terhadap bakteri Escherichia coli. J Ilmu-ilmu Peternak. 2014;24(3):24-31.

12. Susanto, Sudrajat, Ruga R. Studi kandungan bahan aktif tumbuhan meranti merah (Shorea leprosula Miq) sebagai sumber senyawa antibakteri. Mulawarman Sci. 2012;11(12):181-90.

13. Katzung B. Farmakologi Dasar dan Klinik. 10th ed. Publiser E, editor. Jakarta; 2012. 30 p.

14. Asraf M. Uji Sensitivitas Antibiotika 
Pada Isolat Lapang Staphylococcus aureus. Skripsi. Bogor: Institut Pertanian Bogor; 2015. 4 p.

15. Tariq S, Faheem S, Rizvi A, Anwar U. Tetracycline: Classification, Structure Activity Relationship and Mechanism of Action as a Theranostic Agent for Infectious Lesions-A Mini Review. 2018;5(4):1-10.

16. Safitri L, Susilorini T, Surjowardojo P. Evaluasi Aktivitas Antimikroba (Streptococcus Agalactiae) Menggunakan Exstrak Buah Mahkota Buah (Phaleria Macrocarpa L.) Dengan Pelarut Yang Berbeda. J Ilmu dan Teknol Has Ternak. 2017;12(1):8-15.

17. Sylvia Aulia Rahmah S dan S. Uji antibakteri dan daya inhibisi ekstrak kulit manggis (Garcinia mangostana L.) terhadap aktivitas xantin oksidase yang diisolasi dari air susu sapi segar. J online Univ Negeri Malang. 2012;1(1):1-11.

18. Shachi Singh, Swapnil SKV. Antibacterial properties of Alkaloid rich fractions obtained from various parts of Prosopis juliflora. Int J Pharma Sci Res [Internet]. 2011;2(3):114-20. Available from: https://pdfs.semanticscholar.org/de76/d 0398e695b03a218480c0036a6ca6d982 d98.pdf
19. Puspita PE. Aktivitas Antibakteri Ekstrak Tembakau Temanggung Varietas Genjah Kemloko. Institut Pertanian Bogor; 2011.

20. Bonamonte. D, M. V, A. F, M. M, G. A, C. F. Tobacco-induced contact dermatitis. Eur J Dermatology [Internet]. 2016;26(3):223-31. Available from: http://www.embase.com/search/results? subaction=viewrecord \& from=export\&i $\mathrm{d}=$ L613634603\%0Ahttp://dx.doi.org/10 .1684/ejd.2016.2771

21. Lenny H. Kimia Bahan Organik Alam. Bogor: Universitas Pakuan Bogor; 2018. 142 p.

22. Mulyani S, Legowo A, Mahanani A. Viabilitas bakteri asam laktat, keasaman dan waktu pelelehan es krim probiotik menggunakan starter Lactobacillus casei dan Bifidobacterium bifidum. J Indon Trop Anim Agric. 2008;33(2):120-5.

23. Dewi F. Aktivitas Antibakteri Ekstrak Etanol Buah Mengkudu (Morinda citrfolia, Linnaeus) terhadap Bakteri Pembusuk Daging Segar. Universitas Sebelas Maret; 2010. 